\title{
Neuroinformatics based on VRML
}

\author{
Nielsen, Finn Årup; Hansen, Lars Kai
}

Published in:

Neuro Imaging

Publication date:

1998

Document Version

Publisher's PDF, also known as Version of record

Link back to DTU Orbit

Citation (APA):

Nielsen, F. A.., \& Hansen, L. K. (1998). Neuroinformatics based on VRML. In Neuro Imaging Academic Press.

\section{General rights}

Copyright and moral rights for the publications made accessible in the public portal are retained by the authors and/or other copyright owners and it is a condition of accessing publications that users recognise and abide by the legal requirements associated with these rights.

- Users may download and print one copy of any publication from the public portal for the purpose of private study or research.

- You may not further distribute the material or use it for any profit-making activity or commercial gain

- You may freely distribute the URL identifying the publication in the public portal

If you believe that this document breaches copyright please contact us providing details, and we will remove access to the work immediately and investigate your claim 


\section{Neuroinformatics based on VRML \\ F. Å. Nielsen ${ }^{1}$ and L. K. Hansen ${ }^{1}$ \\ ${ }^{1}$ Technical University of Denmark, Lyngby, Denmark}

Neuroimaging experiments based on PET, and in particular on fMRI, are accumulating vast spatio-temporal databases at a rate that calls for new innovative informatics tools. Neuroscience databases are conceptually and physically linked in complex socio-scientific networks of human relations, publications, and funding programs. It is the grand challenge of neuroinformatics to organize these networks and make them transparent for the neuroscience community.

Given the spatio-temporal structure of the data, the dense linking of concepts, and the need for cross-platform interactivity, we find WWW based virtual reality, i.e., VRML - Virtual Reality Modeling Language an obvious tool for neuroinformatics [2]. VRML is a WWW standard adopted by ISO [1]. VRML is a new text-based language (or file-format) for general purpose 3D polygon interactive visualization. There exist VRML viewers for many platforms [3] and they support 3D navigation and geometric "hyperlinking", i.e., by mouse clicks on geometric objects the user can activate links to other Web documents. Dynamic environments are implemented through "behaviors" associated with specific geometric objects. Behaviors can, e.g., be activated by proximity of the users point of view. Future versions of VRML are planned to support multiuser virtual environments.

At our Web site http://hendrix.imm.dtu.dk/vrml there is access to +20 virtual environments illustrating the use of VRML in neuroimaging. Our environments range from displays of 3D brain maps from specific experiments, to abstract representations of neuroscience project infrastructure. In the figure we show an example of an environment summarizing and linking brain map data from a number of experiments in a "value added" Talairach frame of reference. Fiducial markers, grid lines, blob subsets etc. can be included or excluded at the users convenience. At the current level of VRML, available viewers, and the graphics capabilities of standard workstations, we can recommend the use of VRML in neuroinformatics based on the unique possibility for cross-platform communication of $3 \mathrm{D}$ dynamic data and based on the informatics potential of geometric hyperlinking of all types of WWW data including imagery, video, and text. The main drawbacks of current VRML versions are the technological limitations to the complexity of manageable $3 \mathrm{D}$ environments.

Within a not so distant future of high bandwidth WWW, more powerful graphics workstations and support for multiuser VR, VRML could be the Big Bang for neuroinformatics.

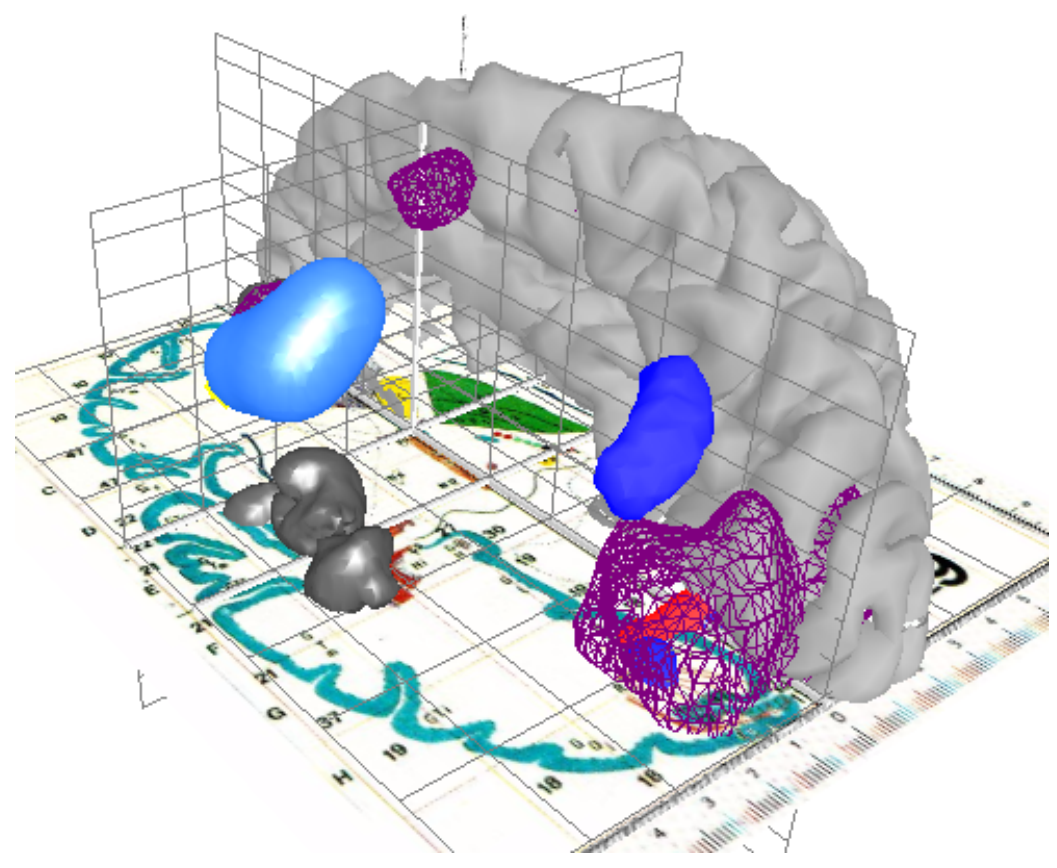

Acknowledgement This project has been funded by The Danish Research Councils and the Human Brain Project P20 MH57180 "Spatial and Temporal Patterns in Functional Neuroimaging".

\section{References}

1. ISO, The Virtual Reality Modeling Language, April 1997, ISO/IEC DIS 14772-1, http://vag.vrml.org.

2. Koslow, S. H., Huerta, M. F., eds., Neuroinformatics, An Overview of the Human Brain Project, Lawrence Erlbaum Associates, 1997.

3. San Diego Supercomputer Center, The VRML Repository, Internet, 1998, http://www.sdsc.edu/vrml/. 